Smith, R. 2019. "'Let us study man as he is, in order to teach him what he should be'" [in English]. Filosofiya. Zhurnal Vysshey shkoly ekonomiki [Philosophy. Journal of the Higher School of Economics] III (4), 11-29.

\title{
ROGER SMITH*
}

\section{«LET US STUDY MAN AS HE IS, IN ORDER TO TEACH HIM WHAT HE SHOULD BE»**}

\begin{abstract}
The eighteenth-century French philosophe Mably, in the declaration used as the title for this paper, articulated a key principle of modern "enlightened" understanding: the demand to use knowledge of the natural laws of human nature as the basis for social policy and social laws. It was the basis for utilitarian social and political thought, and it remains a commonplace of modern Western discourse. I analyse the puzzles and contradictions to which Mably's declaration leads. I then illustrate the arguments with a case study based on Thomas Henry Huxley's lecture, "Evolution and Ethics" (1893). In this lecture, and in other public essays, Huxley argued both for knowledge of "man's place in nature" (i. e. for the scientific study of human conformity to the laws of nature) and the overcoming of natural conditions with moral civilisation. He made different claims in different rhetorical contexts. The paper argues this is the case for all modern Western statements about the laws of human nature detached from the conceptual roots of a belief that there are such laws in Judeo-Christian natural law theory. I emphasise this by drawing in insights from Nietzsche on the desire to "live according to nature", that is, according to the laws of nature. The paper concludes with brief comments on the relevance of the analysis to contemporary statements about the neurosciences as the basis for human self-knowledge and moral action. I refer to statements in the "Ethics and Society" section of the European Human Brain Project.
\end{abstract}

Keywords: Enlightenment, Natural Law, Mably, Huxley, Ethical Naturalism, Human Brain Project, Is / Ought Distinction.

DOI: $10.17323 / 2587-8719-2019-4-11-29$.

\section{I}

Gabriel Bonnot, abbé de Mably, simply known as Mably, the author of the proposal which gives this paper its title, was an Enlightenment historian and moralist ${ }^{1}$. In the revolutionary years in France he had a reputation for maintaining that there is no natural law establishing a right to individual property. He had instead promoted the ideal of communal ownership as the means to the kind of individual virtue republicans thought appropriate for

* Roger Smith, Honorary Fellow at the Institute of Philosophy of the Russian Academy of Sciences, Moscow, rogersmith1945@gmail.com.

** (C) Roger Smith. (C) Philosophy. Journal of the Higher School of Economics.

${ }^{1}$ I have not traced the source of this quotation in Mably's collected works (published posthumously in Paris, in 15 vols., ${ }^{1794-95)}$ but use the English translation in Mably, 1789: 354, cited in Crocker, 1963: 480 . 
a citizen. He was the brother of Étienne Bonnot, better known as Condillac, and Rousseau tutored two nephews of another brother. A. N. Radishchev translated his history of Greece into Russian.

I introduce Mably's proposal in order to examine its meaning and logic as a characteristic statement of "enlightened" thought. I do not say anything about Mably. This paper asks a "simple" question: what does it mean to obey the laws of nature? The question, of course, is not simple at all. Nevertheless, the question uses a form of speech which was very common in Mably's age and is still very common in the present. I seek to defamiliarise the language and suggest that the statement is extremely puzzling. It is the boast of modern science to have demonstrated "man's place in nature", in Thomas Henry Huxley's famous phrase, the place of human beings in the world subject to the operation of natural laws (Huxley, 1906). The boast makes it very important to interpret the language of law; this interpretation proves to be far from simple ${ }^{2}$.

I have rhetorical reasons for choosing Mably's declaration; I do not think that it had any special historical influence. It is a succinct statement of a way of thought, a way of thought still commonplace, a way of presenting the truth of the possibilities for human action. When Mably apostrophised with these words, he stated deeply embedded assumptions about the concept of natural law. Yet, if one stops to analyse his words, it becomes very difficult to agree about what precisely he claimed. Of course, in a general way, the statement that human well-being depends on knowledge of the natural laws of human nature is so conventional as to arouse little comment. It is, for example, the principle of modern medicine. Examined more closely, though, it is perplexing.

Mably's declaration appears to contain a contradiction, or perhaps paradox: if human beings, as a matter of fact, by nature have a particular character, how could they not act according to that character or be taught to have another character? But this question is too slick. To go further, we need to look more closely at the language. I start with some decontextualised comments, not with the study of one author or text. Then, however, I proceed to a historical case study.

${ }^{2}$ I write as an intellectual historian interested in the place of concepts in historically specific argument and discourse. For "classic" historical theses linking notions of a law of nature and human law, and attempting to explain the rise of the notion of natural law in the West and not in China: Zilsel, 1942; Needham, 1951. Zilsel's papers were collected in Zilsel, 2003: and Needham's in Needham, 1969. For the intellectual history of Western jurisprudence: Kelley, 1990. 
Mably's words are exemplary of statements about natural law and human nature, shared across a wide range of modern Western intellectual settings, belonging to what modern authors, speaking loosely, sometimes call "the Enlightenment project". This project - amongst other things - encompasses the theoretical principles and the practices worked up into political economy in the late eighteenth and early nineteenth centuries and into the medical, psychological and social sciences in the nineteenth and twentieth centuries, most definitely including Marxist variants. The most important principle appears almost banal common sense: policy of all kinds should rest on a base of knowledge of the laws of nature to which human beings, like everything else in the world, are subject. Common sense requires policy and practice to have fore-knowledge of the natural properties of things and people. The fore-knowledge that is needed is knowledge of things and people as the means to achieve ends. The same way of thought applies to social actions as to technological innovation ${ }^{3}$.

Mably's proposal goes further, however, because he sought to reveal knowledge in nature of what it is right for a man to do, not just the way to do it ${ }^{4}$. He looked to nature to reveal the ends as well as the means. This is the step where questions most obviously arise (and it has generated a huge philosophical literature). It was, nevertheless, a standard step in the natural law tradition, to which "enlightened" thought gave a new articulation. Scholars have traced the concept of "natural law" to the Ancients - to Aristotle and to the Stoics - and to Christianity and found its most systematic development in Aquinas ${ }^{5}$. Natural law theorists held that the purposes for which humankind exists, or the rational reasons for determining what men and

${ }^{3}$ Critique of this identity of principles was the central theme of the standard reference point in criticisms of "the Enlightenment project": Adorno, Horkheimer \& Cumming, 1986. Separately, it may be questioned how far technological innovation does in fact rely on prior knowledge rather than craft practices.

${ }^{4}$ English-language academic convention requires an explanation for recourse to genderspecific language. Here I adopt eighteenth-century usage. The senses in which reference to "Man" (usually capitalized) then referred to human beings in general and to a specific gender has been extensively argued over. This is not now my focus, though it might have been, since knowledge claims about the different nature of men and women were so prominent a feature of natural law theories.

5"According to natural law moral theory, the moral standards that govern human behaviour are, in some sense, objectively derived from the nature of human beings and the nature of the world. While being logically independent of natural law legal theory, the two theories interact [...] According to natural law legal theory, the authority of legal standards necessarily derives, at least in part, from considerations having to do with the moral merit of those standards" (Himma, 2018). The definition covers a huge range of positions and hides disagreement about 
women "should do", are evident in the natural world, the world that is God's creation (or the outcome of some First Principle). Using modern language, we may say that there was no distinction between the descriptive and the normative force of statements in natural law discourse. The absence of this distinction was rational because of the unity intrinsic in the world as established by the Creator (or First Principle). And this was rational, because of the place of the First Principle or Creator in establishing what "is".

Eighteenth-century "enlightened" re-statements of the natural law argument had a new bite, a cutting edge, because they demanded the study of man as he really is. It was the unstated, implicit message of Mably's declaration: up to the present age, religious authorities, and governance claiming legitimacy in terms of these authorities have been ignorant of, in denial of, or have even lied about what man "is". The radical conclusion was that existing political authorities have presented a picture of men and women based on tradition, prejudice, illusion, and self-interest. The polemical element in Mably's declaration was not the proposal to study man or to draw conclusions about what to do based on that study, but to make that study the study of the experience of nature. Experience, guided by reason, was for "storming 'the Temple of Error", using Buffon's words (quoted in Reill, 2005: 33-70). Medieval natural law theory had combined reason and faith in order to know the conditions of human existence; the faith guaranteed the reason of the normative content of natural law. Eighteenthcentury philosophes like Mably parted company by questioning faith in Revelation and in church-sanctioned authority as the source of knowledge of natural law, arguing instead for reasoning from experience. But they did not disrupt the normative structure of statements about laws of nature. They did not operate with a distinction separating the description of what people do by nature from the description of the purposes for which they do it. (How far, in practice, the philosophes reasoned from experience, rather than reasoned from principles thought to be intuitively rational, is another question, which I put to one side. The crucial point is that what they said distanced arguments about what to do from the earlier ground of those arguments in faith in a Creator ${ }^{6}$.)

which positions are properly addressed as natural law theories. For a brief historical overview: Haakonssen, 1992.

${ }^{6}$ Historically, this needs qualification: many radical "enlightened" thinkers retained a concept of a First Cause, or of a god, which helped sustain the rational content of their use of natural law theory, though their notion of this First Cause tended to be rather abstract and rather distant from the personal God of Christian faith and revelation. 
The pleasure-pain theory of conduct or behaviour was perhaps the most radical and consequential aspect of "enlightened" argument about human nature. From the time of Hobbes and Locke onwards, writers explored the argument that experience reveals the sources, or motives, of human action to lie in the feelings of pleasure and pain accompanying experience. Pleasures and pains are the purposes, or reasons, for which people act or react. The explanation of human action by the constitution of the laws of human feeling exemplified the logic of "enlightened" natural law argument: we know what we should do because we know by experience what are the sources of pleasures and of pains. The way of thought had as its object both the individual and humanity as a whole. The pursuit of pleasures and the avoidance of pains is natural to each and every person, and the pursuit of pleasure and the avoidance of pain for the greatest number of people is, therefore, the natural goal of political society. The study of the individual, revealing her or him as the subject of pleasure and pain, reveals both the means and the purposes of political society. Jeremy Bentham's statement of the argument has acquired canonical status: "Nature has placed mankind under the governance of two sovereign masters, pain and pleasure. It is for them alone to point out what we ought to do, as well as to determine what we shall do. On the one hand, the standard of right and wrong, on the other the chain of causes and effects, are fastened to their throne" (Bentham, 1970: 1). There was, Bentham stated, a necessary relation between "the standard of right and wrong" and "the chain of causes and effects". Mably's declaration presupposed the same relation.

Modern ethical naturalism also presupposes this relation. But what exactly is the relationship between "the standard of right and wrong" and "the chain of causes and effects"? Historically, the relationship was firmly embedded in the language of the religious natural law tradition, in language voicing belief in the unity and meaningfulness of the creation. Yet modern ethical naturalism, like its Enlightenment forerunner, is secular, even anti-religious. If the "chain of causes and effects" exists and is all that exists, what is the imperative force of having a "standard of right and wrong"? The force applies to rest on historical tradition embedded in social conventions, not on religious faith in ultimate meaningfulness. I think that many readers will agree that "tradition" is showing itself to be weak and vulnerable in the contemporary world. This is perhaps most obvious in the elevation of individual feeling over shared truth as the socially legitimating ground of action, and its clearest symptom is the creation or acceptance of news on the basis of feeling, not evidence. This, it might be said, is the contemporary 
form of expression of Mably's principle that we should look to what man "is" in order to know what to do - except that now the feeling of one individual, or one group of individuals, is taken to be the legitimate voice of what man "is". The problem is manifest: feelings, in fact, differ: experience does not reveal which feelings are best. The taking of decisions about what to do is legitimated by feeling, but it is one feeling, belonging to one individual or group and not another, and which feeling dominates depends on power or force and not reason. There is a debate about who has "the right" feelings, rather than about which actions might be reasonable. Mably's principle is eating itself up.

It must be remembered that neither Mably nor Bentham nor indeed the great majority of eighteenth and nineteenth-century writers on moral philosophy and public affairs, worked with a logical distinction between "is" and "ought" statements. Certainly, Hume discussed the distinction, and the distinction was central to Kant's moral theory. But these discussions had limited impact. For the writers whom I am now characterising as the shapers of "the Enlightenment project" it was the very principle of being "enlightened" to take experience to be normative.

This continued to be the case for social and political reform-minded advocates of the psychological and social sciences in the nineteenth and twentieth centuries. In the twentieth century, however, especially in the English-language intellectual world, the is / ought distinction became common currency. It was a very attractive distinction for scholars seeking to professionalise the specialities, whether in the sciences or in philosophy, with which they identified. The scientists claimed independent status as the arbiters of knowledge, while in exchange serving society by presenting it with knowledge as an objective resource not contaminated with pre-judgments about what it is for. These new professional natural and social scientists might have restated Mably, to read: "Let us study men and women as they are, in order for political society to know how to change them to become what society has decided they should be". The philosophers, for their part, turned to the logical analysis of statements and away from moral pronouncements. In both cases, scholars claimed to distance themselves from judgments of values. Then, however, in the latter part of the twentieth century, this intellectual settlement was deeply questioned. Scholars demonstrated the continuities in practice between the modern human sciences and the earlier "enlightened" literature which turned to the experience of nature as a basis for prescriptive action. They showed that liberal as well as Marxist social scientists had indeed worked to implement normative 
social policies based on what was claimed to be true of nature. It appeared that the whole enterprise in which scientists engaged in the pursuit of the truth about laws of human nature had to be understood as cultural activity expressing values, just as it had been in Christian centuries.

II

It will be helpful to turn from abstract comment to a concrete historical case. This case exposes the complexities and contradictions buried in Mably's declaration and in hopes of "enlightened" social policy based on knowledge of nature. I discuss a public lecture, in the University of Oxford, by scientist Thomas Henry Huxley, in 1893. The lecture, "Evolution and Ethics" (Huxley, 1989), gave rise to a buzz of puzzled commentary at the time. It also continues to be cited, in different ways and for different purposes, in public debate about science and policy. It is a reference point in the argument about the ethical dimensions of the evolutionary process and about naturalistic ethics more generally?

Huxley was at first hearing perfectly clear: it is necessary, for the public good, to expand scientific activity and knowledge of the laws of natural evolution: "Nobody professes to doubt that, so far as we possess a power of bettering things, it is our paramount duty to use it and to train all our intellect and energy to this supreme service of our kind. Hence the pressing interest of the question, to what extent modern progress in natural knowledge, and, more especially, the general outcome of that progress in the doctrine of evolution, is competent to help us in the great work of helping one another?" (ibid.: 79) In firmly Victorian, Protestant language, quoting the national poet, Tennyson, Huxley declared: "We are grown men, and must play the man 'strong in will / To strive, to seek, to find, and not to yield', cherishing the good that falls in our way, and bearing the evil, in and around us, with stout hearts set on diminishing it" (ibid.: 86). For all his fame as a fierce defender of the Darwinian theory of evolution, Huxley spoke in the language, even in the biblical cadences, of Christian morality: the will and the intellect, put to use in dedicated scientific activity, are the tools given to us for the service of others. Knowledge of "man's place in nature", that is, of knowledge of the laws to which human beings are subject owing to their evolutionary origin, gives the facts on which Christian morality will instruct us how to act. Science supplies new knowledge of means, but from

7I draw for this case on Smith, 2013: 103-132, "The Moral Agent". 
Christianity, we inherit the knowledge of purposes. However, what Huxley had to say was all a lot more complicated than this.

Thirty years before, Huxley had given another lecture in which he had elaborated on the metaphor of human life as a game of chess played with an opponent who knows and reasons with the rules - "the laws of nature"better than any human player. He took the idea for the metaphor from a picture by a German artist, Moritz A. Retzsch, an engraving of Mephistopheles playing chess with a human partner for the man's soul. Huxley's lecture, as he made clear in the title of the lecture, "A Liberal Education: And Where to Find It" (Huxley, 1868), was a contribution to a public campaign to improve science education and to press British educational culture to recognise science as central to liberal moral values as well as economic interests. For Huxley, learning the discipline of natural science is exemplary training for the moral discipline of independent action according to reason. In Huxley's figure of speech, the master chess-player is a "calm strong angel", and each individual person has no choice but to face this opponent. "The chess-board is the world, the pieces are the phenomena of the universe, the rules of the game are what we call the laws of Nature [...]. And one who plays ill is checkmated - without haste but without remorse" (ibid.: 369). On the one hand, "the rules" are the rules of a "game". In this connection, we must recognise the rich associations in the English culture of games, in which a game is "more than a game" as it teaches the moral discipline of individual effort, team-work, and commitment to social fairness. On the other hand, "the rules", in Huxley's imagery, are absolutes, laws of nature which cannot be disobeyed. The rhetoric had it both ways: the laws cannot be broken and they must be obeyed (implying that can be and are broken). The notion of law served educational and moralistic language propagating a culture of individual effort or will; at the same time, the notion of law implied that nature had absolute coercive character - to follow the laws of nature is to stay alive, to ignore or to fail to obey these laws is to die.

Huxley's figure of speech all too clearly exposed a conundrum: if people are subject to the laws of nature, in what sense can it be said that they can choose to obey or not obey the laws? Huxley wanted to stress that a civilised society has to educate people out of their ignorance of the laws of nature. But he elided the possibility of difference between "has to" and "should". He was also unable to control his listeners' understanding of what he said. He left it open for them to say, or to fear, that humankind is subject whether people are ignorant or knowledgeable - to deterministic law and are in a position in which they have no choice. (In a public argument, 
the Victorians often called this fear, "materialism".) Huxley, in fact, saw something of the problems and never used the imagery of the chess-layer again. Yet his later writings promoting scientific culture also referred to the laws of nature as a source of authority for social policy and argued, as in the concluding message of the lecture on "Evolution and Ethics" already quoted, for the application of shared ethical principles to overcome the effects of laws of nature.

I give two examples of the way Huxley turned to nature as sanction or authority for social policy, that is, treated nature as having normative force, while also arguing for culture to oppose nature. In the 186os, Huxley worked closely with his friend Herbert Spencer on a campaign to enhance national support for the natural and social sciences. In this context, Spencer elaborated on the metaphor of "the social organism" and, in considerable detail, compared the structure and functions of an individual organism with the structure and functions of a society. Strikingly, though, Spencer's strongly-held political individualism led him to deny the analogy between the brain and government as organising powers. Spencer even denied to the government the leading role in organising a national system of education (Spencer, 1868; Spencer, 1874$)^{8}$. Huxley strongly disagreed and supported a national system of education. He, therefore, pointed out what he saw as an inconsistency in Spencer's use of the social organism analogy (Huxley, 1894). The two scientists, the one opposing and the other supporting a centrally directed system of national education, drew different lessons from the natural laws organising organic relations. For Huxley, the experience of nature taught that there is a role for the central government; for Spencer, the experience of nature taught that there is no such role.

The second example. In the $188 \mathrm{os}$, Huxley became concerned at the rise of vigorous working-class political organisations with what he regarded as scientifically ignorant, utopian socialist agendas. In this context, he wrote about the Malthusian law of nature as a central fact of the human condition. Socialist claims were irresponsible, Huxley asserted because they did not take account of the conditions in which any society exists. These conditions existed in Britain, he held, if not necessarily in the form of conditions of struggle for survival, as conditions of struggle for quality of life. This struggle, he went on to say, requires the moral individual, exemplified by

${ }^{8} \mathrm{I}$ also used this example in a contribution to a discussion of metaphor at the Higher School of Economics in Moscow, R. Smith, "Inhibition and Metaphor of Top-Down Organization" (Smith, 2020). 
the scientist, to use reason (which was here the same as experience) and will to seek out and then apply "the facts" for the good of others. Yet in the lecture on "Evolution and Ethics", Huxley appeared to slide from this position into saying that reason and will oppose "the state of nature" described as a state in which struggle conforms to no moral standard. His listeners were very confused about what he was actually saying. He seemed to say that the laws of nature, notably those that lead to brute struggle, are no guide to life. But in other writings, he firmly denounced socialists for opposing the laws of nature.

Statements about the relationship between the laws of nature and the laws of moral civilisation thus depended on the context of the rhetoric. I suggest that statements about laws of human nature always exhibit this dependency on context.

The divergent content of Huxley's statements about the relationship of the laws of nature to human affairs prompts further commentary. First, and most simply, Huxley's contradictory usage was not a personal idiosyncrasy or personal failing; rather, it exemplified the rhetorical position that references to laws of nature had generally in ethical and political debate. The point of my paper is not to pick holes in the logic of individual statements but, rather, to expose the structure of a society's discourse ${ }^{9}$. Nevertheless, it has to be noted that the logical inconsistencies seemingly built into an ethical and political discourse on the laws of nature encouraged philosophers and scientists around 1900 to seek to confine scientific statements to statements of empirical fact and to look elsewhere than in the laws of nature for the ground of ethical judgment. G. E. Moore, for example, named "the naturalistic fallacy" and argued that "the good" exists as a realm independent of nature and is known by the artist and the philosopher rather than the scientist (Moore, 1903). This involved a different kind of claim about what man "is" to the Enlightenment claim, a claim about the nature of an ethical and aesthetic realm and not about human nature. From this viewpoint, it was still possible to accept Mably's proposal, but doing so involved redirecting inquiry about what man "is" away from the investigation of the laws of nature and into a natural ethical realm.

The second comment concerns the normative principles people actually found in the laws of nature. Even at the time Mably made his declaration,

9I would make the same point, for example, commenting on contemporary environmentalist warnings about ignoring laws of nature. There are many parallels between contemporary concerns and the issues which Huxley's lecture addressed. 
Diderot and de Sade were portraying nature as a dubious source (to say the very least) of authority for conventional morality. It was Diderot, not Freud, talking of a small boy, who wrote: "If your little savage were left entirely to himself, if his childish ignorance were left intact, if he were allowed to acquire all the violent passions of a grown man while still remaining as deficient in reason as he had been in his cradle, then he would end up strangling his father and going to bed with his mother" (Diderot, Coltman, 1966: 140). If the facts of human nature are the source of authority for teaching people what to do, then, to be logically consistent, all those facts, including facts about actions which by conventional standards are morally reprehensible (not to say horrific), are sources of authority. Violent nature is as authoritative as benevolent nature. De Sade notoriously took this logic to its conclusion, indeed, followed the logic into the aesthetics of death. Mably and those who thought like him vigorously opposed his position, but they did so, even if they did not know it, with the vulnerable argument that Sade had his facts wrong - people are benevolent, not violent - not that he was wrong in logic.

Just a few years before Huxley's lecture, which I have read as a restatement of Mably's position, Nietzsche had gone to the heart of this issue. I want to quote at greater length. Though Nietzsche's immediate target was Stoic philosophy, what he wrote applied equally to Mably, to Huxley, to utopian speculators on the laws of nature like Kropotkin and to reform-minded, "enlightened" social scientists.

"According to nature" you want to live? O you noble Stoics, what deceptive words these are! Imagine a being like nature, wasteful beyond measure, indifferent beyond measure, without purposes and consideration, without mercy and justice, fertile and desolate and uncertain at the same time; imagine indifference itself as a power - how could you live according to this indifference. Living - is that not precisely wanting to be other than this nature? Is not living - estimating, preferring, being unjust, being limited, wanting to be different? And supposing your imperative "live according to nature' meant at bottom as much as 'live according to life" - how could you not do that? Why make a principle of what you yourselves are and must be?

In truth, the matter is altogether different: while you pretend rapturously to read the canon of your law in nature, you want something opposite, you strange actors and self-deceivers! Your pride wants to impose your morality, your ideal, on nature - even on nature - and incorporate them in her [...] (Nietzsche, Kaufmann, 1966: section 9). 
"Your pride wants to impose your morality". Yes, indeed. This was certainly true of Nietzsche's own pride, exemplified in his demand: "do not mistake me for someone else" (Nietzsche, Kaufmann, 1960: Preface, section 1). But there was the decisive difference that he explored the question at length and did not think that he could turn to a transcendental source, either in the laws of nature or in God, to do the work for him. Nietzsche was not aware of Dostoevsky's Zapiski iz podpol'ya (Letters from Underground), in which the nameless anti-hero, in Nietzsche's words, "estimating, preferring, being unjust, being limited, wanting to be different", acts against the moral law. Here, though Nietzsche might have found exemplary confirmation of his argument. So much, indeed, did the anti-hero of Dostoevsky's novel act against what was understood to be natural and moral that readers in the 1860 s and for some decades thereafter poorly understood the message and dismissed Dostoevsky's portrait as perverse. It took Nietzsche to see, as Dostoevsky had seen, that the desire to know what "is" may be a cruel desire - perhaps itself an ethical principle, but hardly a basis for conventional moral principles ${ }^{10}$.

A final comment concerns the coherence of demanding action in a situation subject to universal, unalterable laws. Nietzsche also examined this problematic and, to many people, intractable issue, closely related to the question of the freedom of the will. I here return to the beginning of the article: what sense can there be in discourse and ways of life committed to knowing the laws of nature as the means to choose rationally what to do. It is an ancient aporia. Christian philosophy had almost talked itself to a standstill with the attempt to reconcile divine omnipotence with human choice and subsequent sinfulness. The same might be said about "enlightened" talk, including its Marxist branches, on agency under the rule of natural law. If we are subject to natural law, we cannot be said to choose to obey it or reject it. Moreover, as Nietzsche wrote: "Why make a principle of what you yourselves are and must be?" Throughout the literature, which this article has exemplified in Mably's declaration and in Huxley's lectures, discourse merged a jurisprudential concept of law, in which it makes perfect sense to refer to breaking the law, and the concept of a law of nature, in which a law is a law precisely because it cannot be broken. The unification of the two positions was an achievement of rhetoric embedded in historical context, the context of the natural law tradition derived from the Greeks

${ }^{10}$ I follow the historical interpretation in Frank, 1986. For Nietzsche on the cruelty of the desire to know, see Nietzsche, Kaufmann, 1966: section 229. 
and the Abrahamic religions. But what then can be said of the relations of the two positions in contexts in which neither the Greeks nor the religions retain their intellectual authority?

III

Spokesmen for science, like Huxley, were, of course, aware of the difference between a social law and a law of nature. Huxley did not, however, make the difference the focus of his attention but, rather, fostered a social imaginary in which human law took its reality and its force from natural law. In Huxley's case, this imaginary was clearly dependent on the continuing strength of Judeo-Christian culture. (Huxley, indeed, though publicly famous as an agnostic, supported study of the bible in state schools as the single most important source of the national moral ethos.) This culture was a kind of inherited moral capital, a source of confidence for relying on education in science and knowledge, that is, for relying on "experience", as the basis for the moral life. This culture persists in some quarters, but it might well be thought that moral capital has diminished.

The title of the paper is taken from the second half of the eighteenth century, and the case study from the second half of the nineteenth century. It is striking that the same analysis is possible in the early twenty-first century, especially for debate around the neurosciences. There is a persistent, deep structure to "enlightened" discourse in the modern age. Its contemporary expression has the form of claims that knowledge of the brain now reveals, or soon will reveal, the basis of what it is to be a person - what man really "is" - and that this knowledge will make it possible fundamentally to control human nature (e.g. aging or mental illness). The contemporary language of debate does not much refer to the laws of nature, but, in this debate those who claim "we are our brains" attribute to knowledge of brains the same putative binding force as earlier generations attributed to laws of nature. The foregoing analysis applies equally in this context.

Knowledge of the brain, pharmacology, computing and information science has, it hardly needs to be said, transformed possibilities for the re-engineering of human beings, perhaps to the extent that future beings will not be recognisable as human by contemporary criteria. But what in principle is new? The difference with the eighteenth century is that writers like Mably thought new knowledge would reveal fixed laws of human nature, like the pleasure-pain principle of behaviour, whereas, now, new knowledge reveals physical neuronal organisation (which is hugely flexible). Moreover, many people now look to technological innovation to provide unprecedented means 
radically to change that organisation - to rebuild what man "is". All the same, the formal structure, as opposed to the content, of argument linking knowledge of what "is" to knowledge of what we "should do" has not changed.

This is not the place to engage the extensive literature on the social dimensions of the neurosciences ${ }^{11}$. I will only confirm the relevance of the foregoing critical analysis of "enlightened" discourse with an illustration. I intend the illustration to show that the forms of knowledge and the skills cultivated in the humanities, the knowledge and the skills needed to interpret references to "laws", continue to have fundamental value- even in "the age of the brain".

The illustration comes from the one-billion Euro Human Brain Project set up in 2013 and coordinated from the École Polytechnique fédérale de Lausanne. The project includes a section on "Ethics and Society" concerned with the parameters of "responsible research". The eminent London sociologist, Nikolas Rose, is one of the leaders of this section ${ }^{12}$. His participation reflects his belief that social scientists have an obligation to engage with social changes actually taking place, as opposed to standing on the sidelines and formulating critical analysis. As he understands events, new "neuro-" knowledge (especially neuropharmacology) is causing deep change, and social scientists have the skills to be players in these changes. Though Rose's personal predilection is not to enter into philosophical questions or old-style ethical discussions about what should be taking place, he has nevertheless made statements with ethical content. He has even voiced an optimistic assessment of the ethical advance made possible by human self-understanding in biological terms: "A somatic ethics is taking shape: the sense that all human beings on this planet are, after all, biological creatures, and that each such creature exercises a demand on each other simply by being a creature of this sort" (Rose, 2007: 55). "Being a creature of this sort", each person, he argues, faces a "demand" in relation to other

${ }^{11}$ For a study of contemporary belief about "brain identity": Vidal, Ortega, 2017.

${ }^{12}$ See Rose, 2018; also the HBP site, www.humanbrainproject.eu/en. As with my comments on Huxley, I cite Rose's position in order to illustrate the structure of a discourse, not to expose supposed inconsistencies in one person's arguments. As it happens, Rose is a scholar from whom, over many years, I have learned a great deal. Moreover, Rose is not a neuro-reductionist: "Not only are human beings understood as persons with mental states that are in constant transactions with their neurobiology; they also have the responsibility - presumably via an exercise of will - to nurture their mental capacities in the light of a knowledge of their brains. We, as persons, must adopt the mental states, the habits, the relationships and forms of life appropriate for this work on our brains - we must shape them as they shape us" (Rose, Abi-Rached, 2013: 163). 
people. The common "demand" comes from a common identity. This shared identity, Rose asserted, is a matter of shared brains: "We have a social brain, in the sense that it now seems that capacities that are crucial to society [e. g. cooperative activity] are a matter of brains. We have a social brain in that the brain has evolved to favor a certain type of sociality manifested in all the interactions between persons and groups that come naturally to humans in our social lives" (Rose, Abi-Rached, 2013: 163). Neuroscientists have studied "man as he is" (in Mably's words) and gained knowledge of his "somatic" identity (Rose's word). Thus the science helps us "teach him what he should be" (again Mably's words) in conformity with the humanist values of which Rose, like many other scientists, and like Mably before him, is an "enlightened" defender. These humanist values are embedded in belief about the shared social nature, and hence - on this understanding ethical character of our brains. And they are embedded in the pursuit of science for the common good.

The foregoing analysis has attempted to make clear the rational difficulties that such statements with ethical character have. I suppose Rose well recognises this. For him, it is perhaps a reason not to engage in $a b$ stract ethical discourse. He has a rhetorical strategy to support doing this: "Ethics, here understood, is a way of understanding, fashioning and managing ourselves in the everyday conduct of our lives" (Rose, 2007: 257). He pushes for better descriptive and analytic tools in social science in order to engage the changes which are actually occurring. But when himself pushed into making ethical statements, he has reiterated "enlightened" ethics a "somatic ethics" based on what man "is". It is, however, the implication of the foregoing analysis of natural law theory to argue that while the neurosciences advance knowledge, the knowledge they advance has nothing new to say about ethical statements.

In its way, Rose's position is implicitly a kind of Aristotelian theory: evolutionary neuroscience makes it possible to have true knowledge of the human species essence which, "in its nature", confers a shared notion of "the good". The position re-expresses in new rhetorical language the old belief that we can find moral law in natural law. The position has a familiar genealogy, which this paper has discussed, and it is subject to familiar problems in reason. These problems are compounded in an age and in a social setting in which natural law theory is not underwritten by faith in a Creator or First Principle.

I also make the further point that the recognition and analysis of this genealogy cannot itself rely on neuroscience. This requires other forms 
of knowledge. This other knowledge is the kind (I trust) expressed in this paper: it is historical knowledge and knowledge of the language and symbolic expression in all its forms.

The paper has discussed central difficulties in the rational articulation of natural law theory. It has focused on the "enlightened" argument that knowledge of the laws of human nature is required in order both to have and to act upon moral laws. Bentham translated the argument systematically into political, ethical and jurisprudential terms, laying the basis for modern utilitarian forms of argument. To modern ears, trained to draw a logical distinction between factual (descriptive) and evaluative (prescriptive) statements, there appears something logically incoherent in Mably's declaration. Yet such declarations were central to natural law theories, and such declarations, or something resembling them, have been and remain commonplace in modern discourse. To illustrate this, I introduced a case study of statements both coupling and de-coupling the laws of nature and human laws in Huxley's discussion of evolution and ethics. Huxley articulated different kinds of statements for different purposes in different contexts. This was not a personal failure on his part but, on the contrary, displayed a rich awareness of the profound rhetorical resources of the languages of law. The contemporary turn to seek foundations for being human in evolutionary neuroscience has given these rhetorical resources a new life.

To examine the genealogy of notions of law, however, is to confront the problematic rational content of the rhetoric. In the eighteenth century, the argument that knowledge of the laws of nature must be the guide to know what to do had a radical cutting edge: its force came from setting up the authority of nature in opposition to the authority of revealed knowledge. But, crucially, the argument did not provide the resources with which to reflect on itself as discourse - just as the modern neurosciences do not. Reflective knowledge requires knowledge of history, genealogy, rhetoric and the kind of knowledge for which the humanities disciplines exist. Reflection is constituted in the analysis of scientific knowledge as a form of knowledge and not in the presumption that such knowledge constitutes a uniquely authoritative form of truth. There was a kind of nobility in Mably's declaration, as there was in Huxley's campaign for scientific culture, but it was precisely that nobility, not rational authority. 


\section{REFERENCES}

Adorno, T., and M. Horkheimer. 1986. Dialectic of Enlightenment. Trans. from the German by J. Cumming. London: Verso.

Bentham, J. 1970. An Introduction to the Principles of Morals and Legislation. Darien: Hafner.

Crocker, L. G. 1963. Nature and Culture: Ethical Thought in the French Enlightenment. Baltimore: Johns Hopkins University Press.

Diderot, D. 1966. "Rameau's Nephew." In Selected Writings, ed. by L. G. Crocker, trans. from the French by D. Coltman. NY: Macmillan.

Frank, J. 1986. Dostoevsky: The Stir of Liberation 1860-1865. Princeton: Princeton University Press.

Haakonssen, K. 1992. "Natural Law Theory." In Encyclopedia of Ethics, ed. by L. C. Becker and C. Becker, 1206-1209. NY: Garland.

Himma, K.E. 2018. "Natural Law." Accessed Mar. 1, 2018. https://www.iep.ut m. edu/natlaw/.

Huxley, T.H. 1868. "A Liberal Education: And Where to Find It. An Inaugural Address." Macmillan's Magazine 17:367-378.

Huxley, T.H. 1894. "Adminstrative Nihilism." In Method and Results : Essays, 251-289. London: Macmillan.

- 1906. Man's Place in Nature and Other Essays. London: J. M. Dent.

- 1989. "Evolution and Ethics." In Evolution and Ethics: T. H. Huxley's Evolution and Ethics: With New Essays on Its Victorian and Sociobiological Context, ed. by G. Paradis and G. C. Williams, 104-144. Princeton: Princeton University Press. Kelley, D. R. 1990. The Human Measure: Social Thought in the Western Legal Tradition. Cambridge (MA): Harvard University Press.

Mably, G. B. de. 1789. [in French]. Vol. 10 of Euvres completes. 12 vols. London: [s. n.] Moore, G.E. 1903. Principia Ethica. Cambridge: Cambridge University Press.

Needham, J. 1951. "Human Laws and Laws of Nature in China and the West." Journal of the History of Ideas 12:3-30, 194-230. 1969. The Grand Titration: Science and Society in East and West. London: Allen \& Unwin.

Nietzsche, F. 1960. Ecce Homo. Trans. from the German by W. Kaufmann. NY: Vintage Books.

- 1966. Beyond Good and Evil: Prelude to a Philosophy of the Future. Trans. from the German by W. Kaufmann. NY: Vintage Books.

Reill, P.H. 2005. Vitalizing Nature in the Enlightenment. Berkeley: University of California Press.

Rose, N. 2007. The Politics of Life Itself: Biomedicine, Power, and Subjectivity in the Twenty-First Century. Princeton: Princeton University Press.

- 2018. "Responsible Research and the Human Brain Project." Accessed Feb. 1, 2018. https://www. youtube.com/watch?v=qa_7Y6H7YM8. 
Rose, N., and J. M. Abi-Rached. 2013. Neuro: The New Brain Sciences and the Management of the Mind. Princeton: Princeton University Press.

Smith, R. 2013. Free Will and the Human Sciences in Britain, 187o-1910. London: Pickering \& Chatto.

. 2020. "Inhibition and Metaphor of Top-Down Organization." Forthcoming, Studies in History and Philosophy of Biological and Biomedical Sciences 79.

Spencer, H. 1868. "The Social Organism." In Essays : Scientific, Political, and Speculative, vol. 1 of Essays : Scientific, Political, and Speculative, 384-428. 3 vols. London: Williams / Norgate.

- . 1874. "The Social Organism." In Essays : Scientific, Political, and Speculative, vol. 1 of Essays : Scientific, Political, and Speculative, 125-170. 3 vols. London: Williams / Norgate.

Vidal, F., and F. Ortega. 2017. Being Brains: Making the Cerebral Subject. New Brunswick: Rutgers University Press.

Zilsel, E. 1942. "The Genesis of the Concept of Physical Law." The Philosophical Review $5^{1}$ (3): 245-279.

. 2003. The Social Origins of Modern Science. Ed. by D. Raven, W. Krohn, and R.S. Cohen. Dordrecht: Kluwer.

Smith R. [Смит P.] "Let us study man as he is, in order to teach him what he should be" [«Дайте нам изучить человека таким, какой он есть, чтобы научить его тому, чем он должен быть»] // Философия. ЖКурнал Высшей школы экономики. - 2019. - Т. III, № 4 . - C. $11-29$.

\author{
РОАЖЕР СМИТ \\ PhD, Почетн. Чл., ИНСтитут ФИлОсОФИИ РАН (Москва)
}

\title{
«ААЙТЕ НАМ ИЗУЧИТЬ ЧЕЛОВЕКА ТАКИМ, КАКОЙ ОН ЕСТЬ, ЧТОБЫ НАУЧИТЬ ЕГО ТОМУ, ЧЕМ ОН АОЛЖЕН БЫТЬ»
}

Аннотация: В максиме, которой озаглавлена настоящая работа, Мабли, французский философ XVIII в., сформулировал ключевой принцип модерного, «просвещенного» понимания: запрос на то, чтобы использовать знание естественных законов человеческой природы как основание для социальной политики и социальных законов. Это было основой утилитаристской социальной и политической мысли, и остается общим местом современного западного дискурса. В настоящей работе я проанализирую затруднения и противоречия, к которым ведет максима Мабли. Затем я проиллюстрирую свои аргументы при помощи тематического исследования лекции Томаса Генри Гексли «Эволюция и этика» (1893). Как в этой лекции, так и в других доступных работах, Гексли одновременно отстаивал и понятие «места человека в природе» (напр., научное изучение человеческого подчинения законам природы) и преодоление естественных условий этической культурой. Он приводил разные аргументы в различных риторических условиях. В настоящей работе полагается, что это действительно для всех современных высказываний о зако- 
нах человеческой природы, оторванных от понятийных корней,- веры в то, что такие законы существуют в иудео-христианской теории права. Я подчеркиваю это, привлекая некоторые озарения из Ницше по поводу желания «жить согласно природе», т. е. согласно законам природы. Работа завершается кратким комментарием насчет применимости такого анализа к современным высказываниям о нейронауках как основании человеческого самопознания и морального действия. Я отсылаю к направлению «Этика и Общество» в рамках европейского Проекта Человеческий Мозг (The Human Brain Project HBP).

Ключевые слова: Просвещение, естественный закон, Мабли, Т. Г. Гексли, этический натурализм, Проект Человеческий Мозг, принцип Юма.

DOI: $10.17323 / 2587-8719-2019-4-11-29$. 